\title{
IMAGE-GUIDED SURGERY IN THE SPINE: NEURONAVIGATION VS. FLUOROSCOPY
}

\author{
CIRURGIA GUIADA POR IMAGEM NA COLUNA VERTEBRAL: \\ NEURONAVEGAÇÃO VS. FLUOROSCOPIA \\ CIRUGÍA GUIADA POR IMAGEN EN LA COLUMNA VERTEBRAL: \\ NEURONAVEGACIÓN VS. FLUOROSCOPÍA
}

Vinícius de Paula Guedes ${ }^{1}$, Elisangela Ferrretti Manffra² ${ }^{2}$ Luiz Roberto Aguiar ${ }^{2}$

\begin{abstract}
Objectives: To evaluate the accuracy and the operative complications of implanting pedicle screws in the thoracic and lumbar spine, using computer-assisted surgery compared to the implantation technique using fluoroscopy. Methods: A retrospective study was conducted at the Hospital Universitário Cajuru PUC-PR from January 2000 to January 2009. Two groups of patients undergoing implant pedicle screws were analyzed $(n=80)$. Group I received implant pedicle screws through fluoroscopy technique and group II, through neuronavigation technique. The accuracy of positioning of pedicle screws was evaluated using rating scales. Results: The accuracy was higher in group II, where $77.5 \%$ of the screws were correctly positioned, whereas there were only $28.5 \%$ in group I $(p=0.001)$. There was a reduction of $95 \%(\mathrm{Cl}$ : $80-97 \%)$ in the risk of screws misplacement in group II. The average operation time was $312.2 \pm 78.1$ minutes in group I and $270.3 \pm 41.4$ in group II $(p=0.004)$. Blood transfusion was needed in 28 patients in group I and 10 patients in group II $(p=0.005)$, resulting in 64\% risk reduction of blood transfusion in group II. Eight patients in group I underwent revision surgery whereas only one patient in the group II, that is, $75 \%$ of surgical revision risk reduction. Conclusion: The implantation technique of pedicle screws using neuronavigation is a more accurate method and has less operative complications compared with the technique that uses fluoroscopy.
\end{abstract}

Keywords: Spine/surgery; Surgery, computer-assisted; Neuronavigation; Fluoroscopy.

\section{RESUMO}

Objetivos: Avaliar a precisão e as complicações operatórias do implante de parafusos pediculares na coluna torácica e lombar, utilizando o método de cirurgia assistida por computação comparada à técnica de implante utilizando fluoroscopia. Métodos: Um estudo retrospectivo foi realizado no Hospital Universitário Cajuru PUC/PR de janeiro de 2000 a janeiro de 2009. Dois grupos de pacientes submetidos a implante de parafusos pediculares foram analisados $(n=80)$. O grupo I recebeu implante de parafusos pediculares com técnica de fluoroscopia e o grupo II, com técnica de neuronavegação. A precisão dos parafusos pediculares foi avaliada utilizando-se escalas de graduação. Resultados: A precisão do posicionamento dos parafusos foi superior no grupo II, no qual 77,5\% dos parafusos estavam corretamente posicionados, enquanto havia somente $28,5 \%$ no grupo I $(p=0,001)$. Houve $95 \%$ (IC: $80-97 \%)$ de redução do risco de mau posicionamento de parafusos no grupo II. A média de tempo cirúrgico foi de 312,2 \pm 78, 1 minutos no grupo l e 270,3 $\pm 41,4$ no grupo II ( $p=0,004)$. Houve necessidade de transfusão sanguínea em 28 pacientes do grupo I e em somente 10 no grupo II ( $p=0,005)$, resultando em 64\% de redução de risco de transfusão sanguínea no grupo II. Oito pacientes no grupo I foram submetidos à revisão da cirurgia enquanto somente um no grupo II, ou seja, 75\% de redução de risco de revisão cirúrgica. Conclusão: A técnica de implante de parafusos pediculares utilizando neuronavegação é um método mais preciso e tem menor complicações operatórias quando comparada com a técnica que utiliza a fluoroscopia.

Descritores: Coluna vertebral/cirurgia; Cirurgia assistida por computador; Neuronavegação; Fluoroscopia.

\section{RESUMEN}

Objetivos: Evaluar la precisión y las complicaciones operatorias de la implantación de tornillos pediculares en la columna torácica y lumbar, utilizando el método de cirugía asistida por computación en comparación con la técnica de implantación mediante fluoroscopía. Métodos: Un estudio retrospectivo se llevó a cabo en el Hospital Universitário Cajuru PUC-PR desde enero de 2000 a enero de 2009 . Se analizaron dos grupos de pacientes sometidos a implante de tornillos pediculares $(n=80)$. El grupo I ha recibido implantación de tornillos pediculares con la técnica fluoroscópica y el grupo II, con la técnica de neuronavegación. La exactitud de la colocación de los tornillos pediculares se evaluó mediante escalas de clasificación. Resultados: La precisión de la colocación de los tornillos fue mayor en el grupo Il, en el que 77,5\% de los tornillos fueron correctamente colocados, mientras que sólo había 28,5\% en el grupo / ( $p=0,001)$. Hubo 95\% (IC: $80-97 \%$ ) de reducción en el riesgo de mala posición de tornillos en el grupo II. El tiempo quirúrgico promedio fue de 312,2 \pm 78,1 minutos en el grupo I y 270,3 $\pm 41,4$ en el grupo // $(p=0,004)$. Hubo necesidad de transfusión de sangre en 28 pacientes del grupo / y sólo 10 en grupo II ( $p=0$, 005), lo que resulta en la reducción del riesgo del $64 \%$ de las transfusiones de sangre en el grupo II. Ocho pacientes del grupo I se sometieron a cirugía de revisión, mientras que sólo un paciente en el grupo II, es decir, el 75\% de reducción del riesgo de revisión quirúrgica. Conclusión: La técnica de implantación de tornillos pediculares utilizando neuronavegación es un método preciso y tiene menos complicaciones operatorias en comparación con la técnica que utiliza la fluoroscopía.

Descriptores: Columna vertebral/cirugía; Cirugía asistida por computador; Neuronavegación; Fluoroscopía.

1. Universidade Católica de Pelotas (UCPel), Pelotas, RS, Brazil.

2. Pontifícia Universidade Católica do Paraná (PUCPR), Health Technology Graduate Program, Curitiba, PR, Brazil. 


\section{INTRODUCTION}

The fixation of the thoracic and lumbar spine and of the thoracolumbar segment with pedicle screws has been used routinely to treat spinal pathologies. The management of traumatic, congenital and degenerative disorders are examples of their main applications. ${ }^{1-3}$ Special care should be taken when implanting pedicle screws as improper positioning may lead to neurological and vascular lesions as well as arthrodesis failure. The implantation of pedicle screws has traditionally been performed using anatomical references with the assistance of fluoroscopy. Knowledge of the relationships of anatomical structures allows the surgeon to determine the entry point of the screws, and they use intraoperative radiological imaging (plain radiography and/or fluoroscopy) to direct the pedicle screws appropriately. ${ }^{4-7}$ The precision of this technique depends on the surgeon's ability to perceive the positioning of the pedicle and the quality of the intraoperative images. Kyphotic deformities, anatomical variances and bone density are some challenges faced by surgeons when implanting pedicle screws. Due to these factors, studies that analyze the pedicle screw implantation technique guided by anatomical references and fluoroscopy exhibit high rates $(15-30 \%)$ of misplaced screws. . $^{8-10}$

Image-guided surgery in the vertebral column is a computer-based technology that allows three-dimensional reconstruction of the spine. In order to perform the surgical procedure, both images derived from imaging tests (computed tomography) and the patient's anatomy are cross-referenced through a process called point registration. Afterwards the intraoperative anatomical points are visualized in a three-dimensional coordinate system. In this way the surgeon can visualize, in real time, on the computer screen, the exact position of an instrument applied on the surface of one of the patient's spinal structures. This is only possible as the instrument applied is equipped with LEDs or reflector elements that are captured by a system of cameras which are connected to the computer that processes the images. ${ }^{6,11-15}$

Cadaveric ${ }^{16-23}$ and clinical ${ }^{8,24-29}$ studies have demonstrated that neuronavigation in the vertebral column is a safe and accurate method that is more effective than conventional methods for implanting pedicle screws. In a clinical study comparing the precision of the positioning of pedicle screws in the thoracic and lumbosacral spine between the two methods, the authors found an error in the positioning of screws of $13.4 \%$ in the conventional surgery group and only $4.6 \%$ in the group that used neuronavigation. ${ }^{8} \mathrm{~A}$ second study showed a positioning error of $23 \%$ with the use of fluoroscopy and only $2 \%$ with neuronavigation. ${ }^{25}$ Despite all this evidence, neuronavigation is still a questionable method to be considered a gold standard method for pedicle screw implantation. Controversial data regarding the increase in surgical time for pedicle screw implantation, intraoperative bleeding and positioning of screws in the thoracic spine mean that neuronavigation is still a questionable method. In a retrospective comparative study, Sakai et al. ${ }^{29}$ demonstrate a superior result of the neuronavigation group with more accurate positioning of screws than the control group. Although the average time spent on surgery has been longer in the fluoroscopy group, there was no statistically significant difference between the means. Moreover, there was no difference between the mean values of blood loss between the groups analyzed either. On the other hand, in a prospective study Laine et al. ${ }^{8}$ demonstrates a longer time frame when conventional surgery was used.

In a meta-analytic review, Kosmopoulos and Schizas ${ }^{30}$ reviewed 130 retrospective and prospective, clinical and cadaveric studies. In a total of 33,000 screws implanted in the cervical, thoracic and lumbar spine, an improvement was noted in the precision of the positioning of pedicle screws using the neuronavigation technique in the lumbar spine. However, there was no statistically significant difference when the neuronavigation technique for implanting pedicle screws in the thoracic spine was compared with the other techniques.

In the meta-analytic review by Tian and $\mathrm{Xu},{ }^{31} 54$ studies were analyzed. The studies included evaluated the use of three image- -guided surgical techniques (neuronavigation), two-dimensional fluoroscopy and three-dimensional fluoroscopy in. The authors of this study also divide the types of studies into cadaveric and in vivo. The relative risk of pedicle screw misplacement using the neuronavigation technique was analyzed with results showing that the relative risk of misplacement of pedicle screws is lower for the use of image-guided surgery as compared to the other techniques. However, there was no statistically significant difference when thoracic levels were analyzed.

It can be inferred from this literature review that although the neuronavigation method is considered more accurate, there is still no consensus regarding the upper thoracic levels. In addition, issues relating to the time spent on surgery with the navigation method and intraoperative bleeding have not yet been fully clarified. Moreover, the body of evidence on the comparison of the navigation method with fluoroscopy consists of only two randomized studies and two retrospective comparative studies.

\section{METHODS}

This study was conducted retrospectively at the Neurosurgery Department of Hospital Universitário Cajuru PUC/PR, through the review of medical records of the patients who underwent implantation of pedicle screws in the thoracic and/or lumbar spine between January 2000 and February 2009, following authorization from the IRB (Institutional Research Board), opinion 003575/09. The patients' identity was not revealed at any time in the selection, collection and analysis of data.

The patients' medical records were only included in the study if they contained complete information about the patient as well as details regarding the type of surgery and whether neuronavigation was used or not. Data relating to the surgical time and need for blood transfusions were obtained from the anesthesia fact sheet. In addition, it was compulsory to append a pre- and postoperative computed tomography of the spine to the medical records.

Eighty medical records were included and divided into two groups, the first with patients who underwent pedicle screw implantation using fluoroscopy and the second formed of patients who underwent implantation of screws using the navigation technique with the Stryker I navigation system.

Aiming to avoid learning curve bias, the medical records were analyzed retrospectively from the latest to the most recent cases in which the fluoroscopy system was used (selecting 40 records), covering the period from January 2005 to January 2000. Medical records were also selected for the navigation group, but this time covering the period from January 2009 to January 2005.

Patient details such as age, gender, diagnosis, type of surgical procedure, and postoperative complications were extracted from the analysis of the medical records and entered in an Excel table (Microsoft Office). The OsiriX program was employed to analyze the images using the DICOM protocol.

Two evaluators blinded to the procedure used analyzed the images and classified them according to Figure 1.

The chi-square and Student's- $t$ tests were used to measure the association of categorical data and means between the two groups. Relative risk reduction was used to measure the efficiency of the pedicle screw implantation, blood transfusion and revision surgery when the navigation system was used. A p-value below 0.05 was considered for statistical significance.

\section{RESULTS}

From January 2000 to January 2005, 350 patients underwent implantation of pedicle screws, all of which were inserted using the fluoroscopy method. From January 2005 to January 2009, 410 patients underwent implantation of pedicle screws using the navigation method. In each group the 40 most recent medical records were analyzed. The most relevant demographics and clinical data are summarized in Table 1. 


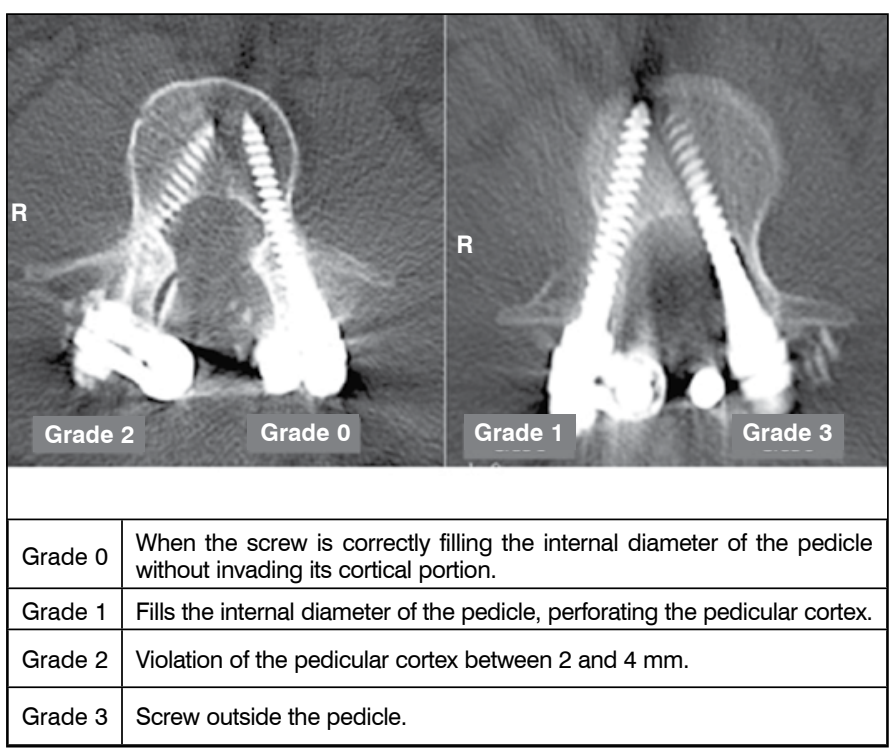

Figure 1. Image analysis using the DICOM protocol.

There was no statistically significant difference between the groups in terms of age, gender, surgical indication, diagnosis and number of screws implanted per patient.

A total of 186 and 200 screws were analyzed in group I and II, respectively. The distribution between spinal levels was similar between the two groups with no differences even when analyzing the upper thoracic surgery subgroup. The mean number of screws per patient was $4.6 \pm 1.7$ screws/patient in Group I and 5.0 \pm 1.7 in Group II ( $p=0.03)$.

In Table 2 it is possible to analyze the statistically significant differences between the groups when analyzing the positioning of pedicle screws. A relative risk reduction of $93 \%$ was observed in relation to pedicle screw misplacement when the neuronavigation system was applied. In addition, when the need for blood transfusion was analyzed, a greater need was noted in Group I (28 patients) while in Group II only 10 patients required a transfusion, thus having a relative risk reduction of $64 \%$ in the need for blood transfusion and of $75 \%$ in the need for reoperation (Table 3). Moreover, the surgical time was seen to be longer in Group I (320 $\pm 78.1 \mathrm{~min})$ than in Group II (270 \pm 41.3 min) (Figure 2).

Table 1. Demographic distribution.

\begin{tabular}{c|c|c|c}
\hline & Group I & Group II & $\mathbf{p}$ \\
\hline No. Patients & 40 & 40 & $>0.05$ \\
\hline No. Male patients & 29 & 28 & $>0.05$ \\
\hline No. Female patients & 11 & 12 & $>0.05$ \\
\hline Age & $40.6 \pm 16.4$ years & $46.0 \pm 17.0$ years & 0.15 \\
\hline Pathology & & & \\
\hline Thoracic fracture & 18 & 11 & 0.31 \\
\hline Lumbar fracture & 15 & 22 & 0.33 \\
\hline Others & 7 & 7 & 1 \\
\hline
\end{tabular}

Table 2. Classification of pedicle screw placement.

\begin{tabular}{c|c|c}
\hline & Group I & Group II \\
\hline Grade 0 & 53 & 155 \\
\hline Grade I & 80 & 41 \\
\hline Grade II & 37 & 3 \\
\hline Grade III & 16 & 1 \\
\hline
\end{tabular}

The main factor associated with reoperation was the misplacement of pedicle screws in both groups, yet Group II had a risk reduction for reoperation of $75 \%$ compared to Group I. Besides reoperation, surgical site infection and CSF leak were the main postoperative complications found in both groups. (Table 4)

Table 3. Relative risk reduction.

\begin{tabular}{c|c|c|c}
\hline Outcome & Group I & Group II & Relative risk reduction \\
\hline Screws grade II and III & $53 / 186$ & $4 / 200$ & 0.9298 (Cl: 0.8099-0.9741) \\
\hline $\begin{array}{c}\text { Need for } \\
\text { Blood Transfusion }\end{array}$ & $28 / 40$ & $10 / 40$ & 0.6429 (Cl: $0.3661-0.7988)$ \\
\hline Reoperation & $8 / 40$ & $2 / 40$ & $0.7500(\mathrm{Cl}:-0.1051-0.9434)$ \\
\hline
\end{tabular}

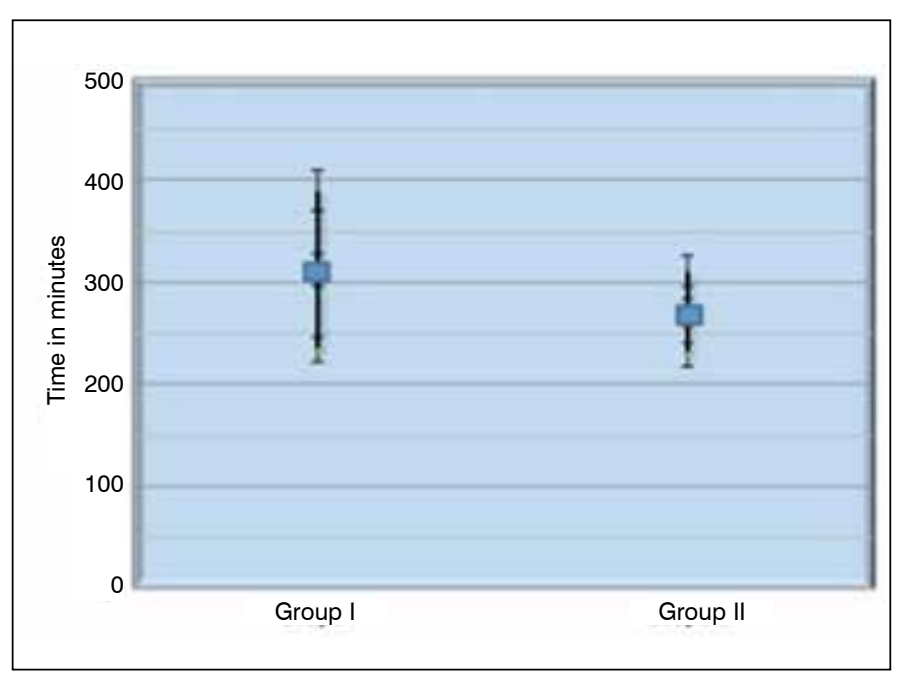

Figure 2. Distribution of total surgical procedure time $(p=0.004)$.

Table 4. Postoperative complications.

\begin{tabular}{c|c|c|c}
\hline & Group I & Group II & p \\
\hline Reoperation & 8 & 2 & 0.04 \\
\hline Infection & 4 & 2 & 0.67 \\
\hline Cerebrospinal fluid leak & 3 & 2 & 1 \\
\hline
\end{tabular}

\section{DISCUSSION}

\section{Demographic Analysis}

The high incidence of fractures of the thoracic and lumbar spine in this study is related to specific characteristics at the institution where the study was conducted. Hospital Universitário Cajuru is one of the primary centers of reference for multiple trauma patients from the city and region of Curitiba/state of Paraná (PR).

\section{Positioning of Pedicle Screws}

An adequate evaluation of the placement of pedicle screws requires both an effective classification instrument, and appropriate acquisition of images for this classification to be applied. Most studies use computed tomography with thin slices (between 1 and 3 $\mathrm{mm}$ ) to analyze the placement of the pedicle screws. ${ }^{8,25,29}$ However, the acquisition methodology is not always described. Only one study uses nuclear magnetic resonance ${ }^{27}$ to analyze the position of the screw in the pedicle, which may lead to distortions when analyzing the images. In this study it was not possible to control this outcome. Due to the characteristics of the retrospective study, the patients 
could not be submitted to further tests. However, the tomographic cross-sections analyzed follow a particular sectioning pattern of 1 to $3 \mathrm{~mm}$. Furthermore, in some prospective $\mathrm{e}^{8,27,29}$ studies for the control of this possible analysis bias, the image represented by the largest section of the pedicle was studied.

In a recent literature review in a meta-analytic study, which verifies the accuracy of pedicle screw placement in the cervical, thoracic, lumbar and sacral spine, the author found more than 35 types of classification for the placement of pedicle screws. The type of classification found most often was the one that evaluated only the presence or absence of pedicle violation. ${ }^{30}$ The lack of a standard for the analysis of screw positioning in the pedicle may often lead to distorted and controversial results. ${ }^{8}$ In this study, we elected to use the scales used most frequently by the other authors that compare the neuronavigation and fluoroscopy techniques for pedicle screw implantation in the thoracic and lumbar spine. .,25,29,32 $^{2}$

As regards the classification of the placement of screws in the pedicle, most studies indicate proper placement of the screw in the pedicle using the neuronavigation technique. In the study by Amiot et al. ${ }^{27} 5.4 \%$ perforated the pedicular cortex and were classified as grade 1 , while there were no cases with screws placed beyond $2 \mathrm{~mm}$ from the pedicular cortex. In the study by Laine et al., ${ }^{8}$ of the 219 screws applied using computer-assisted surgery, $4.6 \%$ perforated the wall of the pedicle in some direction or another. In the current study we observed results that are slightly different from these first studies, yet similar to those of the study by Sakai et al. ${ }^{29}$ The latter features perforation of the pedicular cortex of $22.3 \%$ of the screws implanted with the navigation system, of which $11.3 \%$ were beyond $2 \mathrm{~mm}$ from the pedicular cortex. With the tomography-guided surgical method, in this study we obtained a rate of $23 \%$ of pedicle perforation, yet only $2 \%$ of the screws were more than $2 \mathrm{~mm}$ beyond the pedicular cortex

Studies that analyze the placement of pedicle screws with the use of fluoroscopy show that there is misplacement of the screws in the pedicle, ranging between $21-40 \%$ in most series. ${ }^{9.33} \mathrm{Ho}$ wever, neither the classification criteria of these studies nor the postoperative image acquisition method are clear. Comparative studies exhibit results ranging from 46 to $13 \%$ of misplacement of pedicle screws with the conventional technique. The current study shows a rate of $71.5 \%$ of screws that violate the pedicle cortex in some direction, data that are very different from the results of the other series. However, it can be noted that most of these misplaced screws are in Group I (43\%), and that when we analyze the screws that violate the pedicle cortex above $2 \mathrm{~mm}$, we obtain a result similar to the other series. This may be related to the way the postoperative images were analyzed. Although the largest cross-section of the pedicle was always observed, the radiological images or films in which most of the tests could be found in Group I did not accurately exhibit the actual screw placement. It is important to emphasize that there was no statistically significant difference between the classifications of the evaluators, with Kappa $=0.92$.

As regards the upper thoracic spine subgroup, the literature is still somewhat divergent in relation to results. In the retrospective study by Youkilis et al., ${ }^{32}$ the authors analyzed 224 pedicle screws applied in the thoracic spine, of which only $8.5 \%$ were misplaced (grade 2 or 3). In the systematic review by Kosmopoulos and Schi$\mathrm{zas}^{30}$ the authors state that neuronavigation does not increase the accuracy of pedicle screw placement in the thoracic spine. The current study shows superiority of the neuronavigation approach in relation to the implantation of screws in the upper thoracic spine. Only two screws (8.4\%) were classified as grade 2 or 3 , out of a total of 24 screws applied. With the fluoroscopy method this proportion increases to $57 \%$ (16 screws). An equal number of pedicle screws were noted in the upper thoracic spine, classified as grade 1 between the groups analyzed. This finding is correlated with the morphological characteristics of the thoracic pedicle. As this is an extremely narrow pedicle, when the screw penetrates the pedicle it may violate the pedicular cortex along its course. The study by Amiot et al. ${ }^{27}$ shows that there was no violation of the pedicular cortex in any of the pedicle screws implanted in the upper thoracic spine using the neuronavigation system. The other prospective comparative studies do not yield results in relation to the implantation of pedicle screws in the upper thoracic spine.

As reported by Laine et al., ${ }^{8}$ a comparative analysis between study results is rather difficult to conduct as there is no uniformity between the image acquisition criteria postoperatively and no uniform pedicle screw classification criteria.

Although not showing the same outcome incidences as the literature analyzed, as refers to the accuracy of neuronavigation as an isolated method, it becomes clear that a comparative analysis between the two methods produced results similar to those of the literature analyzed. ${ }^{5,8,18.27}$ Most studies comparing fluoroscopy with neuronavigation demonstrate superiority of the second method, with statistically significant differences.

\section{Surgical Time}

As this study was conducted retrospectively with an analysis of medical records, surgical time to implantation was counted as a whole from the start of the surgical procedure until its conclusion, and it was not possible to measure the time required for the implantation of each pedicle screw separately. Randomized and experimental $\left.\right|^{5,9,19}$ prospective studies demonstrate that the surgical time is greater when the neuronavigation method is used to implant pedicle screws. However, in the study by Mirza et al., ${ }^{3}$ the surgeons had no experience with the method, and in the in vitro study by Assaker et al., ${ }^{19}$ none of the 10 surgeons had used the neuronavigation system employed in the study. The implantation of pedicle screws using the computer-assisted surgical system needs the surgeon to have a learning curve with adequate knowledge of the system and preoperative planning. ${ }^{8}$

In this study the surgical time was found to be shorter in the group that used the computer-guided surgical system. This finding is probably associated with the surgeon's experience and familiarity with the method. This fact can be checked and compared, due to the manner in which the medical records were selected, in reverse chronological order, which makes it possible to analyze the maximum time of the surgeon's experience and familiarity with both surgical methods.

\section{Blood Transfusion}

Few studies report data in relation to intraoperative bleeding and compare this outcome between the groups analyzed. The randomized study by Laine et al. ${ }^{8}$ noted a difference, although not statistically significant, between mean values of bleeding. The same result was observed in the study of Sakai et al.. ${ }^{29}$

In this study, the correlation between intraoperative bleeding and transfusion was used as a parameter. It was not possible to quantify the volume of blood transfused during surgery, but we were able to determine whether a blood transfusion was needed during the surgical procedure.

In spite of a statistically significant difference in the incidence of blood transfusions between the groups analyzed, this result should be observed with caution, due primarily to the characteristics of the sample analyzed, which is mainly composed of patients who are trauma victims, a fact that exposes the individual to a number of other factors that may also lead to the need for blood transfusion. However, both groups were homogeneous with regards to age group, pathology and gender. Therefore, even if the trauma factor is associated with blood transfusion, this was the same for both groups. ${ }^{34}$ Furthermore the lower blood transfusion rate associated with neuronavigation observed in this study may be associated with the shorter surgical time and the reduced need to expose the anatomical structures to pedicle screw implantation.

\section{Postoperative Complications}

Changes secondary to the misplacement of pedicle screws such as pain and CSF leak are the main complications. Motor function changes are infrequent findings in the main series of studies. ${ }^{8,27}$ 
Few studies report the reoperation rate. Moreover, they do not report patients in whom screws were found entirely outside the pedicle.

In the current study, we observed a higher incidence of surgical re-intervention in the group that used the fluoroscopy method for pedicle screw implantation, but without evidence that the outcomes, CSF leak, surgical site infection and misplacement of pedicle screws are associated with reoperation.

The differences in incidence of cerebrospinal fluid leaks and surgical site between the groups were not statistically significant. The sample characteristics may be associated with these outcomes, as patients with fractures of spinal structures are much more susceptible to CSF leaks, due to the likelihood of bone fragments inside the medullary canal.

\section{CONCLUSIONS}

Based on the results obtained in this study it can be concluded that the neuronavigation system is an effective, accurate and safe surgical method, and a technique superior to fluoroscopy for implanting pedicle screws in the thoracic and lumbar regions of the spine.

All authors declare no potential conflict of interest concerning this article.

\section{REFERENCES}

1. Kabins MB, Weinstein JN. The History of Vertebral Screw and Pedicle Screw Fixation. lowa Orthoped J. 1991;11:127-36.

2. Moore T, McLain RF. Image-guided surgery in resection of benign cervicothoracic spinal tumors: a report of two cases. Spine J. 2005;5(1):109-14.

3. Mirza SK, Deyo RA. Systematic review of randomized trials comparing lumbar fusion surgery to nonoperative care for treatment of chronic back pain. Spine (Phila Pa 1976). 2007;32(7):816-23.

4. Schulze CJ, Munzinger E, Weber U. Clinical relevance of accuracy of pedicle screw placement. A computed tomographic-supported analysis. Spine (Phila Pa 1976). 1998;23(20):2215-20.

5. Mirza SK, Wiggins GC, Kuntz C 4th, York JE, Bellabarba C, Knonodi MA, et al. Accuracy of thoracic vertebral body screw placement using standard fluoroscopy, fluoroscopic image guidance, and computed tomographic image guidance: a cadaver study. Spine (Phila Pa 1976). 2003;28(4):402-13.

6. Berlemann U, Monin D, Arm E, Nolte LP, Ozdoba C. Planning and insertion of pedicle screws with computer assistance. J Spinal Disord. 1997;10(2):117-24

7. Kim YJ, Lenke LG. Thoracic pedicle screw placement: free-hand technique. Neurol India. 2005:53(4):512-9.

8. Laine T, Lund T, Ylikoski M, Lohikoski J, Schlenzka D. Accuracy of pedicle screw insertion with and without computer assistance: a randomised controlled clinical study in 100 consecutive patients. Eur Spine J. 2000;9(3):235-40.

9. Castro WH, Halm H, Jerosch J, Malms J, Steinbeck J, Blasius S. Accuracy of pedicle screw placement in lumbar vertebrae. Spine (Phila Pa 1976). 1996;21(11):1320-4

10. Xu R, Ebraheim NA, OuY, Yeasting RA. Anatomic considerations of pedicle screw placement in the thoracic spine. Roy-Camille technique versus open-lamina technique. Spine (Phila Pa 1976). 1998;23(9):1065-8.

11. Lekovic GP, Potts EA, Karahalios DG, Hall G. A comparison of two techniques in image-guided thoracic pedicle screw placement: a retrospective study of 37 patients and 277 pedicle screws. J Neurosurg Spine. 2007:7(4):393-8.

12. Hüfner T, Gebhard F, Grützner PA, Messmer P, Stöckle U, Krettek C. Which navigation when? Injury. 2004;35(Suppl 1):S-A30-4.

13. Richards PJ Kurta IC Jasani V Jones $\mathrm{CH}$, Rahmatalla A, Mackenzie G, et al. Assessment of CAOS as a training model in spinal surgery: a randomised study. Eur Spine J. 2007;16(2):239-44

14. Arand M, Hartwig E, Kinzl L, Gebhard F. Spinal navigation in tumor surgery of the thoracic spine: first clinical results. Clin Orthop Relat Res. 2002:(399):211-8.

15. Lim MR, Girardi FP, Yoon SC, Huang RC, Cammisa FP Jr. Accuracy of computerized frameless stereotactic image-guided pedicle screw placement into previously fused lumbar spines. Spine (Phila Pa 1976). 2005:30(15):1793-8.

16. Austin MS, Vaccaro AR, Brislin B, Nachwalter R, Hilibrand AS, Albert TJ. Image-guided spine surgery: a cadaver study comparing conventional open laminoforaminotomy and two image-guided techniques for pedicle screw placement in posterolateral fusion and nonfusion models. Spine (Phila Pa 1976). 2002;27(22):2503-8.

17. Ludwig SC, Kramer DL, Balderston RA, Vaccaro AR, Foley KF, Albert TJ. Placement of pedicle screws in the human cadaveric cervical spine: comparative accuracy of three techniques. Spine (Phila Pa 1976). 2000;25(13):1655-67.

18. Hart RA, Hansen BL, Shea M, Hsu F, Anderson GJ. Pedicle screw placement in the thoracic spine: a comparison of image-guided and manual techniques in cadavers. Spine (Phila Pa 1976). 2005;30(12):E326-31.

19. Assaker R, Reyns N, Vinchon M, Demondion X, Louis E. Transpedicular screw placement: image-guided versus lateral-view fluoroscopy: in vitro simulation. Spine (Phila Pa 1976) 2001;26(19):2160-4.

20. Nolte LP, Zamorano LJ Jiang Z Wang $Q$ Langlotz F Berlemann U Image-guided insertion of transpedicular screws. A laboratory set-up. Spine (Phila Pa 1976). 1995;20(4):497-500.

21. Kothe R, Matthias Strauss J, Deuretzbacher G, Hemmi T, Lorenzen M, Wiesner L. Computer navigation of parapedicular screw fixation in the thoracic spine: a cadaver study. Spine (Phila Pa 1976). 2001:26(21):E496-501.

22. Glossop ND, Hu RW, Randle JA. Computer-aided pedicle screw placement using frameless stereotaxis. Spine (Phila Pa 1976). 1996;21(17):2026-34.

23. Sagi HC, Manos R, Benz R, Ordway NR, Connolly PJ. Electromagnetic field-based image-guided spine surgery part one: results of a cadaveric study evaluating lumbar pedicle screw placement. Spine (Phila Pa 1976). 2003;28(17):2013-8.

24. Merloz P, Tonetti J, Pittet L, Coulomb M, Lavalleé S, Sautot P. Pedicle screw placement using image guided techniques. Clin Orthop Relat Res. 1998;(354):39-48.

25. Rajasekaran S, Vidyadhara S, Ramesh P, Shetty AP. Randomized clinical study to compare the accuracy of navigated and non-navigated thoracic pedicle screws in deformity correction surgeries. Spine (Phila Pa 1976) 2007·32(2):E56-64

26. Kalfas IH, Kormos DW, Murphy MA, McKenzie RL, Barnett GH, Bell GR, et al. Application of frameless stereotaxy to pedicle screw fixation of the spine. J Neurosurg. 1995;83(4):641-7.

27. Amiot LP, Lang K, Putzier M, Zippel $H$, Labelle $H$. Comparative results between conventional and computer-assisted pedicle screw installation in the thoracic, lumbar, and sacral spine. Spine (Phila Pa 1976). 2000;25(5):606-14

28. Schwarzenbach O, Berlemann U, Jost B, Visarius $H$, Arm E, Langlotz F, et al. Accuracy of computer-assisted pedicle screw placement. An in vivo computed tomography analysis. Spine (Phila Pa 1976). 1997;22(4):452-8.

29. Sakai $Y$, Matsuyama $Y$, Nakamura $H$, Katayama $Y$, Imagama $S$, Ito $Z$, et al. Segmental pedicle screwing for idiopathic scoliosis using computer-assisted surgery. J Spinal Disord Tech. 2008;21(3):181-6.

30. Kosmopoulos V Schizas C. Pedicle screw placement accuracy: a meta-analysis. Spine (Phila Pa 1976). 2007:32(3):E111-20.

31. Tian $\mathrm{NF}, \mathrm{Xu} \mathrm{HZ}$. Image-guided pedicle screw insertion accuracy: a meta-analysis. Int Orthop. 2009;33(4):895-903.

32. Youkilis AS, Quint DJ, McGillicuddy JE, Papadopoulos SM. Stereotactic navigation for placement of pedicle screws in the thoracic spine. Neurosurgery. 2001;48(4):771-8.

33. Gebhard F, Weidner A, Liener UC, Stöckle U, Arand M. Navigation at the spine. Injury. 2004;35(Suppl 1):S-A35-45.

34. Ribas Filho JMM, Campos O, Melchioretto ACL, Clock EF, Castro FC, Muller GA, et al. Estudo da prevalência dos óbitos por trauma nos principais pronto-socorros de Curitiba no período de abril/2001 a abril/2002 . Rev Méd Paraná. 2002;60(2):45-8. 